\title{
DENSITY INDUCED RATES OF POLLINARIA REMOVAL AND DEPOSITION IN THE PURPLE ENAMEL-ORCHID, ELYTHRANTHERA BRUNONIS (ENDL.) A.S. GEORGE
}

\author{
Raymond L. Tremblay ${ }^{1,10}$, Richard M. BATEMAN ${ }^{2}$, Andrew P. Brown $^{3}$, \\ Marc Hachadourian ${ }^{4}$, Michael J. Hutchings ${ }^{5}$, Shelagh Kell ${ }^{6}$, Harold Koopowitz ${ }^{7}$, \\ CARlos Lehnebach $^{8} \&$ DenNis Wigham ${ }^{9}$
}

\author{
'Department of Biology, 100 Carr. 908, University of Puerto Rico - Humacao campus, Humacao, \\ Puerto Rico, 00791-4300, USA \\ ${ }^{2}$ Natural History Museum, Cromwell Road, London SW7 5BD, UK \\ ${ }^{3}$ Department of Conservation and Land Management, Western Australian Threatened Species \\ and Communities Unit, PO Box, 51 Wanneroo, Western Australia 6065, \\ ${ }^{4}$ New York Botanic Garden, 112 Alpine Terrace, Hilldale, NJ 00642, USA \\ ${ }^{5}$ School of Life Sciences, University of Sussex, Falmer, Brighton, Sussex, BN1 9QG, UK \\ ${ }^{6}$ IUCN/SSC Orchid Specialist Group Secretariat, 36 Broad Street, Lyme Regis, Dorset, DT7 3QF, UK \\ ${ }^{7}$ University of California, Ecology and Evolutionary Biology, Irvine, CA 92697, USA \\ ${ }^{8}$ Massey University, Allan Wilson Center for Molecular Ecology and Evolution \\ ${ }^{9}$ Smithsonian Institution, Smithsonian Environmental Research Center, Box 28, Edgewater, MD 21037, USA \\ ${ }^{10}$ Author for correspondence: raymond@hpcf.upr.edu
}

\begin{abstract}
RESUMEN. La distribución y densidad de los individuos dentro de las poblaciones de plantas pueden afectar el éxito reproductivo de sus integrantes. Luego de describir la filogenia de las orquideas del grupo de las Caladeniideas y su biología reproductiva, evaluamos el efecto de la densidad en el éxito reproductivo de la orquídea terrestre Elythranthera brunonis, endémica de Australia del Oeste. El éxito reproductivo de esta orquídea, medido como la deposición y remoción de polinios, fue evaluado en seis poblaciones de diferentes densidades. Se consideró como baja densidad aquellas poblaciones en las cuales se observó al menos una planta en flor en un radio de $2.5 \mathrm{~m}$ alrededor de una planta focal y como alta densidad a aquellas poblaciones con mas de una planta en un radio de $2.5 \mathrm{~m}$ alrededor de la planta focal. El éxito reproductivo de las plantas focales no fue afectado por la densidad de individuos en ninguna de las 6 poblaciones estudiadas. Sin embargo, cuando se evaluó la suma de las poblaciones en un conjunto, se observó que las plantas focales en poblaciones de mayor densidad tienen una mayor probabilidad de recibir polen. El número de flores por inflorescencia no afectó el éxito reproductivo de los individuos. Al contrario, el numero de flores total en un area de $2.5 \mathrm{~m}$ tenía un mayor éxito reproductivo en el componente de polinios removidos y depositados.
\end{abstract}

\section{Introduction}

Patterns of spatial distribution relative to conspecifics can affect the reproductive success of individual plants in a population if pollinators respond to floral display. Floral display can be perceived at one or more spatial scales by pollinators: the individual flowers, the number of open flowers on an inflorescence, the number of inflorescences on a plant, the number of plants in a definable cluster or in a definable population. The relationship between reproductive success and floral display has been studied in relatively few orchid species and no consistent pattern has yet emerged. For example, fruit production was greatest at intermediate inflorescence densities in
Calopogon tuberosus (Firmage and Cole 1988), greatest at the highest inflorescence densities in Anacamptis (formerly Orchis) morio (Jersáková et al. 2002), and no relationship was detected between inflorescence density and fruit production in Brassavola nodosa (Schemske 1980), Leporella fimbriata (Peakall 1989), Orchis purpurea (Jacquemyn et al. 2002) or Neottia (formerly Listera) cordata (Meléndez-Ackerman \& Ackerman 2001).

Data on the relationship between number of flowers in an inflorescence and fruit set in orchids, while scarce, are also inconsistent. In Lepanthes wendlandii (Calvo 1990), Calopogon tuberosus (Firmage \& Cole 1988), Ionopsis utricularioides (Montalvo \& 
Ackerman 1987), Orchis purpurea (Jacquemyn et al. 2002) and Aspasia principissa (Zimmerman \& Aide 1989), inflorescences bearing more flowers had a higher probability of setting fruit. In contrast, there was no effect of flower number per inflorescence on fruit set in Psychilis krugii (Ackerman 1989), Epidendrum exasperatum (Calvo 1990) or Neotinea (formerly Orchis) ustulata (Tali 1996). Inflorescence size may also affect male and female reproductive success. In Epipactis helleborine, Piper and Waite (1988) showed that the percentage of pollinaria exported and imported increased in a parallel fashion as inflorescence size increased, but the intercepts of the relationships were significantly different. Pollinaria export was significantly greater than pollinaria import at a given inflorescence size.

In this study we investigated two hypotheses related to reproductive success in the deceit-pollinated Purple Enamel-orchid, Elythranthera brunonis (Endl.) A.S. George, a terrestrial species endemic to Western Australia. The first hypothesis was that the reproductive success as measured from pollinaria deposition and removal of individual plants is independent of the local density of conspecific plants. As in neighborhood models of competition between plants (Pacala \& Silander 1985, Jacquemyn et al. 2002), if resources - in this case pollinators - are limited, we would expect reproductive success to be lower in a higher density neighborhood if plants are deceit-pollinated and the animal vector(s) have the capacity to learn rapidly from their mistakes. The null hypothesis would be that more flowering plants per unit area could attract more pollinators, resulting in greater reproductive success per individual in denser populations. The second hypothesis was that both pollen removal (an index of male function) and pollen deposition (an index of female function) would be positively related to inflorescence size. In addition to presenting quantitative tests of these two hypotheses, we review the controversial taxonomic, phylogenetic and distributional contexts of our chosen study species, Elythranthera brunonis, which have not previously been collated in the literature.

\section{Morphology and pollination biology}

\section{Phylogenetic CONTEXT OF POLLINATION.}

A molecular phylogenetic analysis combining the plastid regions matK and trnL-F (Kores et al. 2001, Hopper \& Brown 2004) nested Elythranthera well within the "core Caladeniinae", one of three major clades that together constitute the re-circumscribed tribe Diurideae s.s. Recent morphological taxonomic studies have progressively disaggregated the exceptionally heterogeneous genus Caladenia s.l., so that the "core Caladeniinae" now encompasses ten monophyletic genera, most of them containing few species (cf. Jones 1988, Hoffman \& Brown 1998, Hopper \& Brown 2001b). Four genera successively branch from the base of the clade Caladeniinae. Adenochilus (2 species, Eastern Australian/New Zealand) is succeeded by Eriochilus ( 8 species, mostly Western Australian), then Leptoceras (1 species, Western and Eastern Australian), then Praecoxanthus (1 species, Western Australian). A dichotomy then separates Caladenia s.s. (an estimated 243 mainly Australian species and 19 named hybrids in 6 subgenera) from a five-genus clade consisting of Cyanicula (10 species, both Western and Eastern Australian), Pheladenia (1 species, both Western and Eastern Australian), Ericksonella (1 species, Western Australian), and then the generic pairing of Glossodia (2 species, Eastern Australian) and Elythranthera (2 species, Western Australian) (Hopper and Brown 2004).

Members of the "core Caladeniinae" have a recognizable morphological "gestalt". The small underground tuber generates a single, fleshy leaf at or near the base of the slender stem, which in most cases is strongly hirsute and bears few flowers. The flowers are large relative to most other terrestrial orchids. In many species, the three sepals and two lateral petals are large, rhombic in outline, spreading and brightly colored, suggesting that they are primary visual attractants for pollinating insects. Deviations from this plesiomorphic condition occur in (a) the nearbasal Eriochilus and Leptoceras, where the dorsal sepal and lateral petals are substantially reduced relative to the lateral sepals, and (b) the highly derived spider-orchids of Caladenia subgenus Calonema, subgenus Drakonorchis and subgenus Phlebochilus, which have strongly elongate sepals and lateral petals (e.g. Hopper \& Brown 2001b). In all ten genera, the spurless labellum is well differentiated from the other five perianth segments by being more three-dimensional and much smaller, often possessing a fimbriate margin and/or adaxial calli. Together with the unusually elongate gynostemium, the labellum forms a visual and tactile focus for pollinators. The large gynostemium bears the relatively small, paired acrotenic pollinaria that are characteristic of the diurids (e.g. Dressler 1993, Pridgeon et al. 2001). 
Focusing on the Cyanicula-Glossodia-Elythranthera clade, largely unpublished molecular phylogenetic data for the nrDNA internal transcribed spacer region demonstrate substantial divergence between the three genera (P. J. Kores, 2001, unpublished data; see also the preliminary ITS tree of Kores et al. in Hopper \& Brown 2001a), though the occurrence of rare natural hybrids between Cyanicula and Elythranthera (Hoffman \& Brown 1998) suggests that these genera are not wholly reproductively isolated.

The limited and often anecdotal information currently available (cf. Jones 2001, Dafni \& Bernhardt 1990, A. P. Brown, 2006, unpublished data) suggests that the Cyanicula, Elythranthera, Glossodia, Praecoxanthus and the less derived subgenera of Caladenia s.s. are pollinated by unrewarded bees or, in the case of a few Caladenia and Cyanicula species, by beetles (Kores et al. 2001, A.P. Brown, 2006, unpublished data). Hoverflies and flower wasps are also known to be occasional pollinators, but these insects are thought to be sporadic visitors that rarely transfer pollen. The main exceptions lie in the species-rich genus Caladenia, where many spider-orchids of the more derived subgenera Calonema, Drakonorchis and Phlebochilus experience pheromonally-induced pseudocopulation by thynnid wasps (Stoutamire 1974, 1975, 1981, 1983), although some species also attract bees, flies and/or beetles (Bower 2001a; A.P. Brown, 2006, unpublished data). Glossodia species are pollinated by small bees of the genus Halictus (Jones 1988), as are both species of Elythranthera, which contain yellow-tipped calli that resemble anthers and hence may lure bees in search of pollen (A.P. Brown, 2006, unpublished data).

Thus, the core Caladeniinae encompass a wide range of floral morphologies that reflect an equal diversity of insect pollinators. Within this context, Elythranthera epitomises those genera that are highly attractive to bees but appear to offer them no tangible reward.

\section{MoRPHOLOGY AND AUTECOLOGY OF ELYTHRANTHERA.}

Elythranthera was represented only by E. emarginata in the plastid phylogeny of Kores et al. (2001), but the second species in the genus, E. brunonis, has also been included in the forthcoming ITS phylogeny. This reveals a disparity of only four bases between the two species (P. J. Kores unpublished data. 2001), all perceived as autopomorphies of E. brunonis, suggesting that one species diverged from the other relatively recently.

Both species are distributed throughout south-west Western Australia and have broadly similar floral morphologies. The labellum bears two prominent calli and is smaller than the over-arching gynostemium, which superficially resembles an additional perianth segment due to its exceptionally well-developed lateral wings (see Pridgeon et al. 2001, fig. 28.1, pl. 7). The striking sepals are fleshy exceptionally glossy and somewhat recurved toward the apices.

Of the two species, E. brunonis is the more common, blooms earlier in the spring (between August and early November), is typically taller and bears smaller, purple rather than pink, flowers and more strongly folded labella (Jones 1988, Hoffman \& Brown 1984, 1992, 1998, Brown 1999). Both species experience enhanced flowering following wildfire the previous summer (Hoffman \& Brown 1992, 1998, Brown 1999; Jones 2001). Elythranthera brunonis occurs most commonly on the lateritic soils of the jarrah (Eucalyptus marginata) forest between Perth and Albany, though it is also found in inland woodlands and shrublands, seasonally wet swamplands and in areas of coastal heath over a wide area between Kalbarri on the west coast and Israelite Bay on the south coast. Our study sites encompassed a considerable portion of this geographical and ecological spectrum.

In most communities where it is found, Elythranthera brunonis occurs as scattered individuals (more rarely in small groups) that are typically spaced from $20 \mathrm{~cm}$ to several metres apart. This suggests that plants do not commonly multiply by producing more than one new tuber each year, and hence that reproduction is primarily by seed. It also renders E. brunonis an especially interesting model for the study of the influence of plant density on reproductive success.

\section{Materials and methods}

\section{DATA COLLECTION AND ANALYSIS.}

Data on reproductive success were collected over three consecutive days in September and October 2001 from six populations of Elythranthera brunonis in south-western Australia. each site was visited once during a field trip that immediately followed the $1^{\text {st }}$ World Orchid Conservation Congress in Perth (Dixon et al. 2003). Each of the authors targeted plants by randomly walking through each study site until a plant with at least one open flower was encountered. Once target plants were located, we evaluated the condition of each flower and counted the number fully open, partially open and in the bud stage. For fully open flowers, we determined whether at least 
one of the two pollinaria had been removed from the gynostemium and whether or not pollen had been deposited on the stigma. We also counted the number of other individuals of $E$. brunonis flowering within a radius of $2.5 \mathrm{~m}$ of the target plant. Site locations and details of plant communities at each site are given in Table 1.

The effect on the reproductive success of target plants of being isolated (defined as being the only flowering plant of Elythranthera brunonis within 2.5 $\mathrm{m}$ or more clumped (defined as having at least one other flowering plant of $E$. brunonis within $2.5 \mathrm{~m}$ was tested by using a $2 * 2$ contingency test by randomization. Because some expected frequencies were below 5, the computer program Fish6 Exact Test was used for analyses (Bill Engels, University of Wisconsin, 1992) rather than the Chi square test. To test whether there was a significant relationship between reproductive success and number of plants in a clump, a linear regression analysis was performed with all data combined, including isolated plants. Reproductive success is measured as the number of flowers with pollinaria removed from the bursicles and/or deposited on stigma divided by the total number of fully open flowers.

\section{Results}

\section{Pollen REMOVAL AND DEPOSITION.}

Across all study sites, and irrespective of the number of neighbors around target plants, $10.1 \%$ of the flowers had clear evidence of pollinaria deposition and $15.9 \%$ of the flowers had clear evidence of at least one pollinarium removed.

\section{EFFECT OF INFLORESCENCE SIZE.}

Most plants had only one open flower $(84.3 \%$; $15.2 \%$ and $0.5 \%$ two and three flowered, respectively). The number of pollinaria removed and pollinaria deposited on stigmas did not differ significantly between plants that had two or more open flowers on the inflorescence, as compared with plants possessing only one open flower (Fisher's Exact test, pollinaria removal $\mathrm{p}=0.61$; pollinaria deposition $\mathrm{p}=0.14$ : Table 3).

\section{PlANT ISOLATION AND REPRODUCTIVE SUCCESS.}

The probability of pollinaria being deposited and the probability of pollinaria being removed were not significantly affected by plants being isolated or in clumps when data from each of the six study sites were analyzed separately. However, when data from all sites were combined, the probability of pollinaria being deposited was significantly lower for isolated plants than for plants in clumps (Table 2).

DENSITY-DEPENDENT REPRODUCTIVE SUCCESS AT THE FLOWER LEVEL.

A significant positive correlation $\left(r^{2}=22.5\right)$ was observed between the percentage of flowers with pollinaria removal and the number of flowers within 2.5 $\mathrm{m}$ of the target plant (Kendall Rank Correlation, Tau corrected for ties $0.225, \mathrm{p}=0.0001, \mathrm{n}=136$ ). A less strong, but still significant, positive correlation $(18.5 \%)$ was observed for the percentage of flowers with pollinaria deposited and for number of flowers within $2.5 \mathrm{~m}$ of the target plant (Kendall Rank Correlation, Tau corrected for ties $0.185, \mathrm{p}=0.001, \mathrm{n}$ $=136$ ).

These results could be caused by the high proportion of all the recorded plants that were isolated. Thus, the analyses were repeated without the isolated individuals. The pattern remained the same for the effect of number of plants in the clump on pollinaria removal (Kendall Rank Correlation, Tau corrected for ties $0.268, p=0.006, n=50$ ). However, the relationship between number of neighbors in the clump and the percentage of flowers on which pollinaria had been deposited became insignificant (Kendall Rank Correlation, Tau corrected for ties $0.138, \mathrm{p}=0.16, \mathrm{n}$ $=50)$.

\section{Discussion}

\section{IS ELYTHRANTHERA TRULY DECEPTIVE?}

Fruit production has generally been shown to be low in deceptive orchid species but, based on the literature (Tremblay et al. 2005), one cannot predict whether there will be a positive (e.g. this study; Jacquemyn et al. 2002a), negative (e.g. Fritz \& Nilsson 1995) or neutral (e.g. Fritz \& Nilsson 1995, Alexanderson \& Ågren 1996, Tali 1996) relationship between inflorescence density and reproductive success. The range of responses observed thus far might be due to biological (e.g. pollinator availability, effects of herbivory, reproduction in previous years) and/or environmental controls (e.g. temporal variation in environmental quality and habitat disturbance). However, there is some evidence that reproductive success is temporally variable and that observations need to be made over long periods of time in order to fully understand the complex relationships between pollinators, the environment and the orchids. 
Tremblay et al. - Density effect on reproductive success

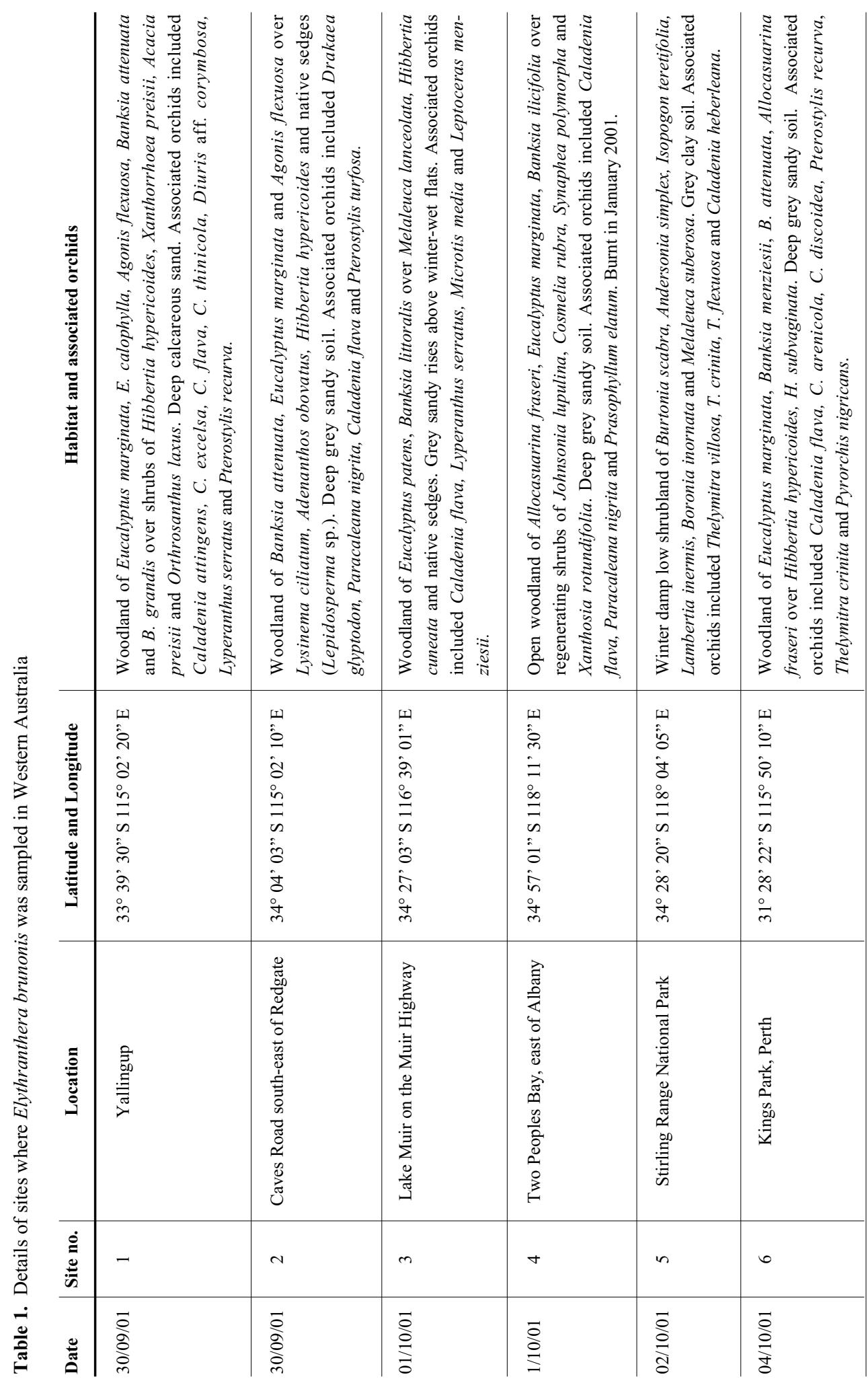




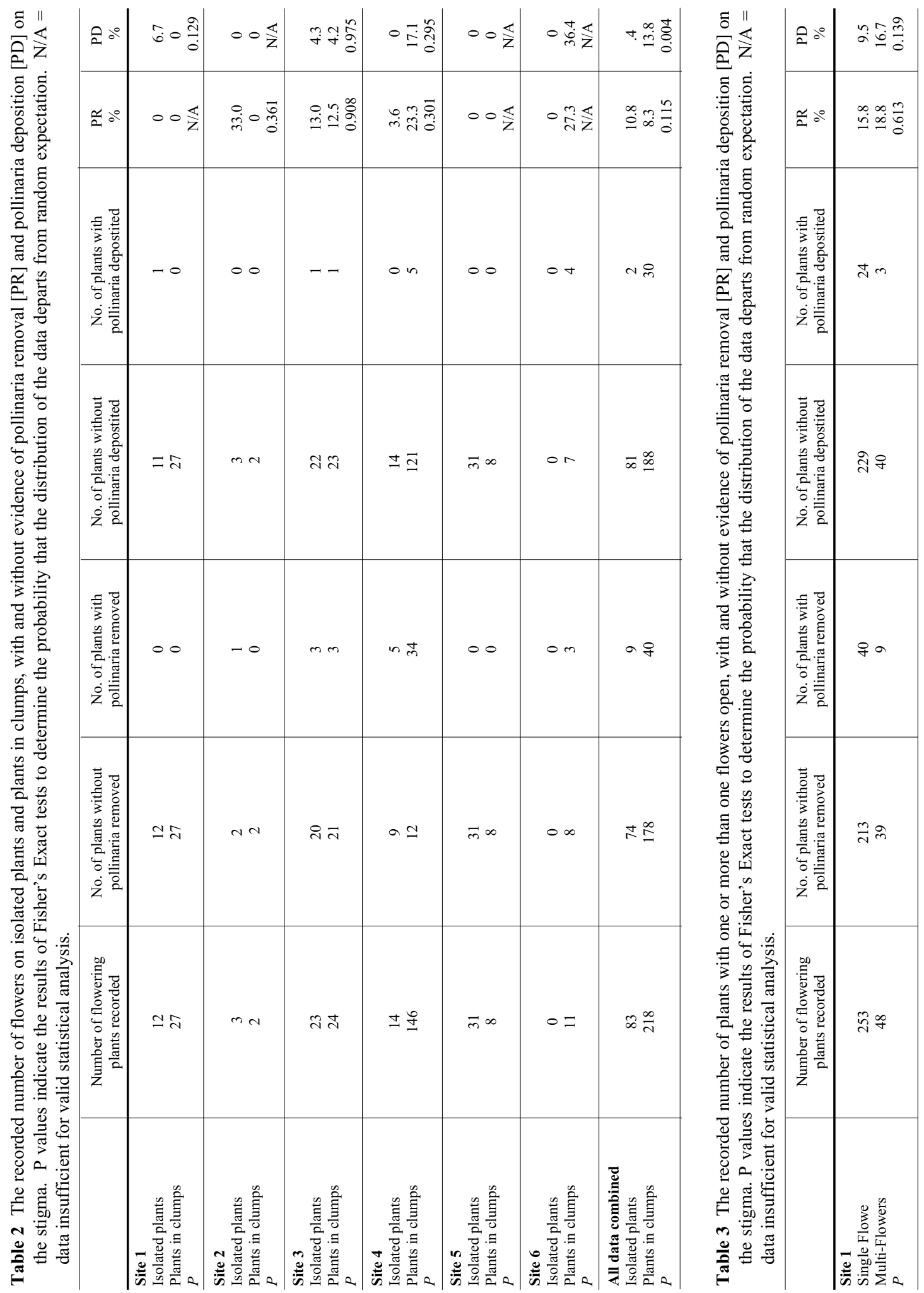


During a multi-year study, Primack and Stacey (1988) consistently found very low levels of reproductive success in Cypripedium acaule, a deceptive slipper orchid. Following major disturbances such as fire and defoliation of trees during a herbivorous insect outbreak, reproductive success was very high but only for a short period of time, and was positively correlated with a large increase in the number of flowering individuals following disturbance. This observation suggests that unpredictable and infrequent events (notably fire in the context of Elythranthera brunonis) may play a major role in determining long-term reproductive success in such species.

Like Cypripedium acaule, Elythranthera brunonis flowers in much larger numbers following summer wildfires (Hoffman \& Brown 1992, 1998), clearly demonstrating that long-term monitoring and both long- and short-term manipulation studies such, as those performed on Cypripedium acaule (Gill 1996, Primack \& Stacy 1998), Neotinea ustulata (Tali 2004), Orchis simia (Willems 2002) and Dactylorhiza fuchsii (Jersaková \& Kindlmann 2002b), are needed to more fully understand the patterns and causes of temporal variation in orchid flowering and reproductive success.

Reproductive success is positively related to inflorescence size in some deceptive orchids (Jacquemyn et al. 2002a), although Calvo (1990) has suggested that it may not be an important factor in many species because of the low levels of pollination inherent in most orchids relative to comparable members of other plant families. Inflorescence size is probably of little consequence for reproductive success in Elythranthera brunonis because of the low variation in number of flowers per inflorescence. However, a study of the potential for selection on inflorescence size in Stegostyla (previously Caladenia) gracilis suggest that, if inflorescence size is genetically inherited and not environmentally determined, the potential for selection is present even if little variation in inflorescence size is observed in the field (Tremblay 2005). Higher reproductive success in clumps and larger floral densities suggests that, if the flowers of E. brunonis are indeed deceptive, the pollinators are slow to learn from their rewardless visits, or that larger groups of flowers are more attractive to potential pollinators. Because individual plants produce few flowers, the reproductive success of this species is mainly influenced by differences in inflorescence

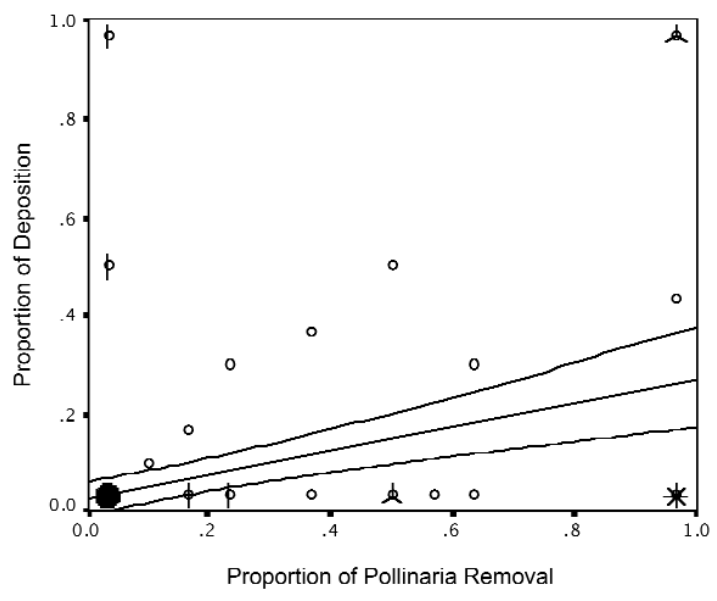

Figure 1 Pollen flux diagram for Elythranthera brunonis. For each individual the proportions of pollinated flowers (pollinaria deposition) is plotted against the proportions of flowers that have experience pollinaria removal. If pollinaria deposition and pollinaria removal occurred simultaneously then the points should lie on the diagonal. However, most of the points lie below this line, indicating that removals occurred prior to pollinaria deposition. The densities of the symbols (bars within a circle) represent larger sample size..

density. It would be interesting to know whether $E$. brunonis is indeed rewardless, and whether physical or chemical pollinator cues are present but have not yet been confidently identified.

\section{REPRODUCTIVE SUCCESS AND POLLINATOR LIMITATION.}

As many studies have shown that orchids are pollinator limited (for an extensive review see Tremblay et al. 2005) we predicted that pollination would be lower in isolated plants. We found that fewer pollinaria were removed from flowers of isolated plants than from plants with close neighbors ( 0.11 vs 0.18$)$, and that the effect of flower isolation on pollinaria deposition was less marked but still significant $(0.02$ vs 0.14 ). These results indicate differences in the effect of local inflorescence density on male and female functional success.

The ratio of pollinaria removed versus pollinaria deposited was approximately 1.5:1 in E. brunonis. This ratio is high relative to that reported for several other orchids (Tremblay et al. 2005). However, a similar ratio was observed in the Puerto Rican species Ionopsis utricularioides $=1.96: 1$ (Montalvo \& Ackerman 1987), Comparettia falcata $=1.35: 1$ 
(Salguero-Faría \& Ackerman 1999), Satyrium bicorne $=0.30: 1$ (Ellis \& Johnson 1999) and Aerangis verdickii $=2: 1-3: 1$ (Light et al. 2004). All of these species offer nectar rewards which are much higher deposition to removal ratio as compared to Central American species Stelis argentata and the Brazilian species Bulbophyllum ipanemense, where the ratios are, respectively, 26.7:1 (Christensen 1992) and 24.2:1 (Borba \& Semir 1998). Once again, the observed visitation rate of $10-15 \%$ suggests that $E$. brunonis is not a deceptive flower or at least offers a higher attracting ability then most deceptive species.

Our results suggest that there is a high efficiency, averaged across all sites, of transfer of pollen to the stigmatic surfaces. Assuming that removal and deposition of pollinaria were recorded with equal accuracy, our data suggest that approximately $64 \%$ of all pollinaria removed were eventually deposited on conspecific stigmas (i.e. there would have been a ratio of three pollinaria removed for every two deposited on a stigmatic surface). At present we are ignorant of the identity of the pollinator, (other than it is a bee in the genus Halictus), and of the mechanism by which the insects are apparently attracted. The ratio of pollinaria deposited to pollinaria removed suggests that the pollination mechanism is effective on those occasions when visitation occurs. Knowledge of the species pollinating E. brunonis might help to explain the high efficiency of pollination.

Since none of the populations behaved significantly differently from each other there is no evidence to suggest that the effect of density on reproductive success is population/site dependent. Moreover, wherever this orchid is present it appears to be a common component of the flora regardless of the extent of its bushland habitat (i.e. small fragmented areas of remnant habitat or of larger areas of intact habitat: A.P. Brown, 2006, unpublished data). The observed variation in population density at the sampled sites may not necessarily represent the range of densities in this species, since fire can affect flowering densities and the fire histories of particular sampled sites are unknown.

If the pattern of reproductive success observed in Elythranthera brunonis during this short survey is consistent over longer periods then E. brunonis is partially affected by the spatial organization of individuals. Clumps of individuals have higher reproductive success through both male and female measures. Local pollination dynamics may be affected by other factors that mask the pollinator behavior in relation to the flowering densities. Furthermore, the high efficiency of pollinations suggests that $E$. brunonis is not a deceptive species and the autecology's of this species should to be investigated in greater depth.

\section{ACKNOWLEDGEMENTS}

We are indebted to Paul Kores and his colleagues for making available information from their unpublished ITS phylogeny, and for critical comments on pollination syndromes, in the Caladeniinae s.s.

\section{Literature Cited}

Ackerman, J.D. 1989. Limitations to sexual reproduction in Encyclia krugii (Orchidaceae). Syst. Bot. 14: 101-109. Ackerman ,J.D. 1990. Inflorescence size and fruit distribution among individuals of three orchid species. Amer. J. Bot. 77: 1378-1381.

Alexandersson ,R. \& J. Ågren. 1996. Population size, pollinator visitation and fruit production in the deceptive orchid Calypso bulbosa. Oecologia 107: 533-540.

Borba E.L. \& S. Semir. 1998. Wind-assisted fly pollination in three Bulbophyllum (Orchidaceae) species occurring in Brazilian campos rupestres. Lindleyana 13: 203218.

Bower, C.C. 2001a. Caladenia: pollination. In: A.M. Pridgeon et al. (eds.). Genera Orchidacearum, 2; Orchidoideae 1. Oxford University Press. pp. 93-97.

Bower, C.C. 2001b. Elythranthera: pollination. In: A.M. Pridgeon et al. (eds.). Genera Orchidacearum, 2; Orchidoideae 1. Oxford University Press. pp. 103-104.

Brown, A.P. 1999. Orchids of the South-West. Department of Conservation and Land Management, Perth, Western Australia.

Calvo, R.N. 1990. Inflorescence size and fruit distribution among individuals of three orchid species. Amer. J. Bot. 77: 1378-1381.

Christensen, D.E. 1992. Notes on the reproductive biology of Stelis argentata Lindl. (Orchidaceae: Pleurothallidinae) in eastern Ecuador. Lindleyana 7: 28-33.

Dafni, A. \& P. Bernhardt. 1990. Pollination of terrestrial orchids of southern Australia and the Mediterannean region: systematic, ecological and evolutionary implications. Evol. Biol. 24: 193-253.

Dixon, K.W., S.P. Kell, R.L. Barrett \& P.J. Cribb (eds.). 2003. Orchid Conservation. Natural History Publications (Borneo), Kota Kinabalu, Sabah, Malaysia.

Dressler, R.L. 1993. Phylogeny and Classification of the Orchid Family. Cambridge University Press, Cambridge. Ellis, A.G. \& S.D. Johnson. 1999. Do pollinators deter- 
mine hybridization patterns in sympatric Satyrium (Orchidaceae) species? Pl. Syste. Evol. 219: 137-150.

Firmage, D.H. \& F.R. Cole. 1988. Reproductive success and inflorescence size of Calopogon tuberosus (Orchidaceae). Amer. J. Bot. 75: 1371-1377.

Fritz, A.L. \& L.A. Nilsson. 1994.How pollinator-mediated mating varies with population size in plants. Oecologia 100: 451-462.

George, A.S. 1963. Notes on western Australian Orchidaceae. III. Elythranthera, a new genus for the enamel orchids. Western Australia Naturalist 9: 2-9.

Gill, D.E. 1996. The natural population ecology of temperate terrestrials: Pink lady's slippers, Cypripedium acaule. In: C. Allen (ed.). North American Native Terrestrial Orchids: Propagation and Production. North American Native Terrestrial Orchid Conference, Germantown, MD. pp 91-106.

Hoffman, N. \& A. Brown. 1984. Orchids of South-West Australia. First Edition. University of Western Australia Press, Nedlands.

Hoffman, N. \& A. Brown. 1992. Orchids of South-West Australia. Second Edition. University of Western Australia Press: Nedlands.

Hoffman, N. \& A. Brown. 1998. Orchids of South-West Australia. Revised Second Edition with supplement. University of Western Australia Press: Nedlands.

Hopper, S.D. \& A.P. Brown. 2001a. Contributions to Western Australian orchidology: 2. New taxa and circumscriptions in Caladenia (Spider, Fairy and Dragon Orchids of Western Australia). Nuytsia 14: 27-314.

Hopper, S.D. \& A.P. Brown. 2001b. Contributions to Western Australian orchidology: 1. History of early collections, taxonomic concepts and key to genera. Nuytsia 14: 1-26.

Jacquemyn, H., R. Brys \& M. Hermy. 2002. Flower and fruit production in small populations of Orchis purpurea and implications for management. In: P. Kindlmann, J.H. Willems \& D.H. Whigham (eds). Trends and Fluctuations and Underlying Mechanisms in Terrestrial Orchid Populations. Backhuys Publishers, Leiden, the Netherlands. pp. 67-84.

Jersákova J., P. Kindlmann \& M. Stritesky. 2002. Population dynamics of Orchis morio in the Czech Republic under human influence. In: P. Kindlmann, J.H. Willems \& D.H. Whigham (eds). Trends and Fluctuations and Underlying Mechanisms in Terrestrial Orchid Populations. Backhuys Publishers, Leiden, the Netherlands. pp. 187-208.

Jersákova, J. \& P. Kindlmann. 2002. Key factors affecting shoot growth and flowering performance of Dactylorhiza fuchsii. In: P. Kindlmann, J.H. Willems \& D.H. Whigham (eds). Trends and Fluctuations and Underlying Mechanisms in Terrestrial Orchid Populations. Backhuys
Publishers, Leiden, the Netherlands. pp. 99-113.

Jones, D.L. 1988. Native Orchids of Australia. Reed Books, Frenchs Forest, Australia.

Jones, D.L. 2001. Subtribe Caladeniinae. In: A.M. Pridgeon et al. (eds.). Genera Orchidacearum, 2; Orchidoideae 1. Oxford University Press. pp. 83-115.

Kores P.J., M. Molvray, P.H. Weston, S.D. Hopper, A.P. Brown A. P., K.M. Cameron \& M.W. Chase. 2001. A phylogenetic analysis of Diurideae (Orchidaceae) based on plastid DNA sequence data. Amer. J. Bot. 88: 1903-1914.

Light M., H. Koopowitz \& T. Marchant. 2003. The impact of climatic, edaphic and physiographic factors on the population behaviour of selected temperate and tropical orchids. In: K.W. Dixon, S.P. Kell, R.L. Barrett \& P.J. Cribb (eds.). 2003. Orchid Conservation. Natural History Publications (Borneo), Kota Kinabalu, Sabah, Malaysia. pp. 357-382.

Meléndez-Ackerman, E.J. \& J.D. Ackerman. 2001. Density-dependent variation in reproductive success in a terrestrial orchid. Pl. Syst. Evol. 227: 27-36.

Montalvo, A.M. \& J.D. Ackerman. 1987. Limitations to fruit production in Ionopsis utricularioides. Biotropica 19: 24-31.

Pacala, S.W. \& Jr. Silander. 1985. Neighborhood models of plant population dynamics I. Single-species models of annuals. Amer. Naturalist 125: 385-411.

Peakall, R. 1989. The unique pollination of Leporella fimbriata (Orchidaceae): pollination by pseudocopulating male ants (Myrmeca urens, Formicidae).Pl. Syst. Evol. 167: 137-148.

Piper, J.G. \& S. Waite. 1988. The gender role of flowers of broad-leaved helleborine, Epipactis helleborine (L.) Crantz (Orchidaceae). Functional Ecology 2: 35-40.

Pridgeon, A.M., P.J. Cribb, M.W. Chase \& F.N Rasmussen (eds). 2001. Genera Orchidacearum. 2. Orchidoideae, Part 1. Oxford University Press, Oxford.

Primack, R. \& E. Stacy. 1988.Cost of reproduction in the pink lady's slipper (Cypripedium acaule, Orchidaceae): An eleven-year experimental study of three populations. Amer. J. Bot. 85: 1672-1679.

Sabat, A.M. \& J.D. Ackerman. 1996. Fruit set in a deceptive orchid: the effect of flowering phenology, display size, and local floral abundance. Amer. J. Bot. 83: 11811186.

Salguero-Faría, J.A. \& J.D. Ackerman. 1999. A nectar reward: is more better? Biotropica 31:303-311.

Schemske, D.W. 1980. Evolution of floral display in the orchid Brassavola nodosa. Evolution 34: 489-493.

Snow, A.A. \& D.F. Whigham. 1989. Cost of flower and fruit production in Tipularia discolor. Ecology 70: 1286-1293.

Stoutamire, W.P. 1974. Australian terrestrial orchids, thynnid wasps, and pseudocopulation. Amer. orch. Soc. Bull. 
43: 13-18.

Stoutamire, W.P. 1975. Pseudocopulation in Australian terrestrial orchids.Amer. orch. Soc. Bull. 44: 226-233.

Stoutamire, W.P. 1981.Pollination studies in Australian terrestrial orchids. National Geographic Society Research Reports 13: 591-98.

Stoutamire, W.P. 1983. Wasp-pollinated species of Caladenia (Orchidaceae) in South-western Australia. Austral. J. Bot. 31: 383-394.

Tali, K. 1996. Spring-flowering and summer-flowering populations of Orchis ustulata L. (Orchidaceae) in Estonia; their comparison and distribution. J. Europ. Orch. 28: 573-582.

Tali, K. 2004. Species structure in Neotinea ustulata. PhD Thesis, University of Tartu, Tartu, Estonia.

Tremblay, R. L., J.D. Ackerman, J.K. Zimmerman \& R.
Calvo. 2005. Variation in sexual reproduction in orchids and its evolutionary consequences: a spasmodic journey to diversification. Biol. J. Linnean Soc. 84: 1-54.

Tremblay, R.L. 2005. Larger is better: The effect of floral display on reproductive success in two populations of Caladenia (Stegostyla) gracilis R. Br. Muelleria 22: 7785.

Willem, J. 2002. A founder population of Orchis simia in the Netherlands. In: P. Kindlmann, J.H. Willems \& D.H. Whigham (eds). Trends and Fluctuations and Underlying Mechanisms in Terrestrial Orchid Populations. Backhuys Publishers, Leiden, the Netherlands, pp. 2333.

Zimmerman, J. K. \& T.M. Aide. 1989. Patterns of fruit production in a neotropical orchid: pollinator vs. resource limitation. Amer. J. Bot. 76: 67-73.

Richard Bateman is an evolutionary biologist and palaeobiologist who has studied orchids for most of his life. His particular interests are morphological and molecular phylogeny reconstruction, species delimitation, and saltational explanations of major steps in evolution. He is currently a Research Associate at the Royal Botanic Gardens Kew, Head of Policy at the Biosciences Federation, Visiting Professor at the University of Reading, President of the Systematics Association and of the UK Hardy Orchid Society, and Vice President of the Linnean Society.

Andrew Brown is a conservation biologist and taxonomist who has studied orchids for much of his life. Andrew has authored numerous papers and publications on Western Australian orchids and in particular has been involved in naming over 150 new Western Australian taxa, has co-authored Orchids of South-west Australia and is currently preparing a new book covering all the Western Australian orchid species. Apart from the Orchidaceae Andrew is interested in the Mypoporaceae and has prepared text for a soon to be published field guide on Eremophila. He is currently the State Threatened Flora Coordinator based in the Western Australian Department of Environment and Conservation's Species and Communities Branch and, as such, coordinates research, recovery and other work on threatened Western Australian plants. Andrew is a life member of the Western Australian Native Orchid Study and Conservation Group, and a member of the Australian Orchid Foundation and Australasian Orchid Specialist

Marc Hachadourian is the Curator of Glasshouse Collections for the New York Botanical Garden. He is a graduate of Cornell University and holds a degree in Plant Science. He actively participates in conservation studies and contributes his expertise in ex-situ conservation of all types of plants. He has studied and observed orchids in the wild in South America, Australia,Europe, South Africa and Australia. With active interests in taxonomy and conservation, Mr. Hachadourian has dedicated himself to increasing public awareness about the importance of global plant conservation and the appreciation of plant biodiversity.

Michael J. Hutchings is a population ecologist who has studied orchids for thirty years. He also researches into the ecology of clonal plant species and the effects of environmental heterogeneity on individual plants, plant competition, and the performance of populations and communities of plants. He is Professor of Ecology at University of Sussex, UK, and Executive Editor of Journal of Ecology. 
Shelagh Kell was Executive Officer of the IUCN/SSC Orchid Specialist Group from 1998-2003 and in 2001 initiated and co-founded Orchid Conservation International. She is currently Author, Supervisor and Associate Examiner for the University of London External Programme (UK), Honorary Research Associate at the University of Birmingham (UK), Consultant Editor for the International Plant Genetic Resources Institute (Italy) and Programme Manager for the IUCN/SSC Crop Wild Relative Specialist Group.

Harold Koopowitz is professor emeritus in Biology at the University of California at Irvine. His research interests range from conservation biology of orchids to the reproductive biology of tropical orchids. In addition, he specializes in the taxonomy of the genus Paphiopedilum. He does field research on causes of rarity and commoness in the amaryllid genus Narcissus.

Carlos Lehnebach is currently finishing his $\mathrm{PhD}$ research on the Radiation and phylogenetic affinities of New Zealand Alpine Ranunculus at Massey University, New Zealand. He has previously studied the pollination ecology of New Zealand's epiphytic and terrestrial orchids and the Chilean orchid flora (taxonomy and conservation issues). His research interests include adaptive radiation and speciation processes, phylogenetic affinities between NZ and South American plants and orchid pollination ecology and conservation.

Raymond L. Tremblay is a senior professor at the University of Puerto Rico at the Humacao campus and is a member of the graduate faculty at the Rio Piedras campus. He is presently chair of the In situ conservation Committee of the OSG. His interests are varied including evolutionary processes and conservation biology of orchids. Much of his present work involves population viability analysis.

Dennis F. Whigham is a Senior Scientist and Deputy Director at the Smithsonian Environmental Research Center in Edgewater, Maryland and Professor of Landscape Ecology at Utrecht University in The Netherlands. His research involves the broad topic of how plants interact with their environment and how those interactions affect ecological processes. He is a member of the Orchid Specialist Group IUCN. His research currently emphasizes populations dynamics and orchid-fungal interactions. 